\title{
Quantification of Phytophthora capsici Oospores in Soil by Sieving-Centrifugation and Real-Time Polymerase Chain Reaction
}

\author{
C. F. Pavón, M. Babadoost, and K. N. Lambert, Department of Crop Sciences, University of Illinois, Urbana, \\ 61801
}

\begin{abstract}
Pavón, C. F., Babadoost, M., and Lambert, K. N. 2008. Quantification of Phytophthora capsici oospores in soil by sieving-centrifugation and real-time polymerase chain reaction. Plant Dis. 92:143-149.
\end{abstract}

A procedure was developed to quantify Phytophthora capsici oospores in soil by combining a sieving-centrifugation method and a real-time quantitative polymerase chain reaction (QPCR) assay. Five soil samples representing three different soil textures were infested with oospores of $P$. capsici to produce $10^{1}, 10^{2}, 10^{3}, 10^{4}$, or $10^{5}$ spores per $10 \mathrm{~g}$ of air-dried soil. Each $10 \mathrm{~g}$ sample of infested soil was suspended in $400 \mathrm{ml}$ of water and then passed through 106-, 63-, and $38-\mu \mathrm{m}$ metal sieves. The filtrate was then passed through a $20-\mu \mathrm{m}$ mesh filter. Materials caught on the filter were washed with water into two 50-ml centrifuge tubes and spun for $4 \mathrm{~min}(900 \times g)$. The pellet was suspended in $30 \mathrm{ml}$ of $1.6 \mathrm{M}$ sucrose solution and centrifuged for $45 \mathrm{~s}(190 \times \mathrm{g})$. The supernatant was passed through the $20-\mu \mathrm{m}$ mesh filter. The sucrose extraction process of oospores was repeated five times to maximize oospore extraction. Materials caught on the $20-\mu \mathrm{m}$ mesh filter were washed with water into a 50-ml tube and spun for $4 \mathrm{~min}(900 \times \mathrm{g})$. The pellet was suspended in $1 \mathrm{ml}$ of water, and the number of oospores was determined with a haemocytometer. The relationship between number of oospores recovered from the soil and number of oospores incorporated into the soil was $\hat{Y}=-0.95+1.31 X-0.03 X^{2}\left(R^{2}=0.98\right)$, in which $\hat{Y}=$ $\log _{10}$ of number of oospores recovered from the soil and $X=\log _{10}$ of number of oospores incorporated into the soil. The oospores were germinated after treatment with $0.1 \% \mathrm{KMnO}_{4}$ solution for $10 \mathrm{~min}$ to induce germination. On the basis of the detection of ribosomal DNA, a QPCR method for $P$. capsici oospores was developed. PCR inhibitors were eliminated by extracting oospores from the soil by sieving-centrifugation. DNA was extracted and quantified from $P$. capsici oospores with suspensions of $10^{1}, 10^{1.5}, 10^{2}, 10^{2.5}, 10^{3}, 10^{3.5}, 10^{4}, 10^{4.5}$, and $10^{5}$ oospores per $\mathrm{ml}$ of water. The relationship between the DNA quantities and number of $P$. capsici oospores was $\hat{Y}=-3.57-0.54 X+0.30 X^{2}\left(R^{2}=0.93\right)$, in which $\hat{Y}=\log _{10}$ (nanogram of $P$. capsici DNA) and $X=\log _{10}$ (number of oospores). The relationship between the quantity of DNA of $P$. capsici oospores recovered from the soil and the number of oospores incorporated into the soil was determined by $\hat{Y}=-3.53-0.73 X+0.32 X^{2}\left(R^{2}=0.955, P<0.05\right)$, in which $\hat{Y}=\log _{10}$ (DNA quantity of $P$. capsici oospores recovered from the soil) and $X=\log _{10}$ (number of $P$. capsici oospores incorporated into the soil). Utilizing the sieving-centrifugation and QPCR methods, oospores of $P$. capsici were quantified in soil samples collected from commercial fields.

Additional keywords: Capsicum annum, Cucurbita moschata, Cucurbita pepo, Phytophthora blight, TaqMan assay

Phytophthora capsici Leonian is a soilborne oomycete plant pathogen that infects more than 50 crops and several weed species $(12,43)$. It can infect plants at any stage of growth, causing Phytophthora blight with symptoms such as seedling damping-off, crown rot, foliar blight, and fruit rot $(3,4,12,18)$. Phytophthora blight, caused by $P$. capsici, causes as much as $100 \%$ crop losses in cucurbits, eggplant, and peppers in the United States and worldwide $(3,12,18,21,27)$.

Corresponding author: M. Babadoost

E-mail: babadoos@uiuc.edu

Accepted for publication 22 August 2007.

doi:10.1094/PDIS-92-1-0143

(C) 2008 The American Phytopathological Society
Illinois growers produce more than $90 \%$ of processing pumpkins in the United States and Phytophthora blight has been the most serious threat to the processing pumpkin industry in the past decade (3). Also, $100 \%$ crop losses in bell pepper fields in Illinois have been reported (23). $P$. capsici has also been reported to cause significant losses in vegetable industries in Michigan (18). Currently, adequately effective strategies for achieving commercially acceptable management of $P$. capsici have not been identified. The recommended measures for control of this pathogen include cultural practices $(12,18)$, fungicide application $(4,18,23)$, and genetic resistance in peppers $(18,23)$.

$P$. capsici is a heterothallic organism in which two compatible mating types, A1 and $\mathrm{A} 2$, are needed for sexual reproduction (12). Both mating types are found in the
United States $(12,18,23)$, often in the same field (23). The sexual spore of $P$. capsici is the oospore, which is the overwintering propagule in the soil and primary source of inoculum $(7,12)$. Determining oospore density in the soil is essential for establishing effective cropping systems for managing $P$. capsici. The impediments for monitoring $P$. capsici oospores in the soil were primarily the difficulties in extracting them from the soil (26) and developing reliable sampling protocols that would estimate precise oospore densities (35). Methods used for assessing the density of $P$. capsici oospores in the soil have been dilution plating on semiselective culturing media and baiting assays $(12,26,33)$, but these procedures are time consuming, labor intensive, and less reliable. Serological techniques have also been developed for Phytophthora species, but there is a lack of species-specific antibodies $(25,30,35)$.

The sieving-centrifugation with sucrose solution is basically a method to separate particles based on their size and density. Several studies have been conducted using sieving-centrifugation with a sucrose solution to separate propagules of mycorrhizal fungi (9), teliospores of Tilletia species (5), and nematodes (24) from the soil.

Real-time quantitative polymerase chain reaction (QPCR) is a relatively new molecular technique that has been used to quantify nematodes (8), viruses (13), bacteria $(6,34)$, and fungal and oomycete plant pathogens $(14,16,19,40)$. QPCR was first introduced by Huguchi et al. (20), in which the increment of intensity of fluorescence was quantified with time during the exponential phase of DNA amplification. Technological advances in QPCR-based methods in the past few years allow fast, accurate detection and quantification of plant pathogens (32).

Relative QPCR is a technique that is usually used for gene expression profiling (36), but can also be used in quantitative environmental studies (16). One of the methods used for relative QPCR is the $\Delta \Delta \mathrm{Ct}$ method (29), which is based on the relative detection of two DNA sequences: the target and endogenous control. For an adequate quantification with the $\Delta \Delta \mathrm{Ct}$ method, two conditions need to be met: (i) the amplification efficiency of both sequences is equal; and (ii) the endogenous control quantity is equal among the different samples (29). 
Molecular tools have been used to conduct in-depth studies of the biology of the genus Phytophthora (2,19,39-41). Silvar et al. (41) used a polymerase chain reaction (PCR)-based method to detect $P$. capsici. Also, Silvar et al. (40) developed a QPCR assay for quantification of $P$. capsici in pepper plants, but these methods cannot be used to quantify $P$. capsici oospores in the soil because of the presence of PCR inhibitors in the soil (44). The objective of this research was to develop a reliable procedure by combining a sieving-centrifugation method and a QPCR assay to quantify $P$. capsici oospores in the soil.

\section{MATERIALS AND METHODS}

In vitro oospore production. Isolates of $P$. capsici were collected from infected pumpkin and zucchini plants in Illinois. The collected isolates were paired with $P$. capsici isolates A1 (15427) and A2 (15399) obtained from the American Type Culture Collection (Manassas, VA) to evaluate their oospore-producing potential. Using the isolates with high oosporeproducing ability, oospores were produced in $250-\mathrm{ml}$ glass flasks containing $30 \mathrm{ml}$ of $\mathrm{V} 8-\mathrm{CaCO}_{3}$ medium (38). The flasks were incubated at $24^{\circ} \mathrm{C}$ in darkness for 2 months. Then, oospores were harvested by blending the culture at full speed in a blender (Model 52250; Hamilton Beach, Southern Pines, NC) for $90 \mathrm{~s}$. The suspension in the blender was passed through 63and $38-\mu \mathrm{m}$ metal sieves and a $20-\mu \mathrm{m}$ Spectra/Mesh nylon filter (Spectrum Inc., Houston, TX). Oospores caught on the 20$\mu \mathrm{m}$ filter were collected and used in the following studies.

Extraction and enumeration of $\boldsymbol{P}$ c capsici oospores in the soil. Five soil samples from commercial fields representing three soil textures (Table 1) were passed through a 2-mm sieve and air dried at room temperature on a laboratory bench for 14 days. The soil samples (500 g each) were autoclaved twice at $157^{\circ} \mathrm{C}$ for $1 \mathrm{~h}$ each time. An oospore suspension was prepared and the number of oospores in the suspension was determined with a spore-counting chamber (Haemocytometer No. 3120; Hausser Scientific, Horsham, PA). Oospore suspensions with desired densities of $10^{1}, 10^{2}, 10^{3}, 10^{4}$, and $10^{5}$ spores per $\mathrm{ml}$ of sterile distilled water were prepared. The oospore suspension was mixed with a vortex (Maxi Mix; Barnstead/Thermolyne,
Dubuque, IA) prior to adding to the soil, 1$\mathrm{ml}$ aliquot of the oospore suspension was added to each $10 \mathrm{~g}$ of soil and the soil sample was thoroughly mixed. The artificially infested soil samples had $10^{1}, 10^{2}$, $10^{3}, 10^{4}$, and $10^{5}$ P. capsici oospores per $10 \mathrm{~g}$ of air-dried soil. A noninfested control sample was included for each soil.

Each $10 \mathrm{~g}$ of infested soil sample was suspended in $400 \mathrm{ml}$ of tap water and two drops of Tween 20 were added and stirred for 15 min with a stirring plate (Barnstead/Thermolyne). The soil suspension was then passed through 106-, 63-, and 38$\mu \mathrm{m}$ metal sieves, and the sieves were washed with a fine sprinkler with a gentle stream of water and the filtrate was collected. This suspension (approximately 2 liters) was passed through the $20-\mu \mathrm{m}$ mesh filter. The materials caught on the $20-\mu \mathrm{m}$ filter were washed with water into two 50$\mathrm{ml}$ centrifuge tubes and spun for $4 \mathrm{~min}$ $(900 \times g)$ with a bench-top centrifuge (Centra-CL2; International Equipment Company, Needham Height, MA). The supernatant was discarded and the pellet was suspended in $30 \mathrm{ml}$ of $1.6 \mathrm{M}$ sucrose solution. This suspension was then centrifuged for $45 \mathrm{~s}(190 \times g)$ and the resulting supernatant was passed through the $20-\mu \mathrm{m}$ filter. The sucrose-oospore extraction steps were repeated five times to maximize oospore recovery from the soil. The materials caught on the $20-\mu \mathrm{m}$ mesh filter were washed with water into a 50-ml centrifuge tube and spun for $4 \mathrm{~min}(900 \times g)$. The pellet was resuspended in $1 \mathrm{ml}$ of distilled water and enumerated with the sporecounting chamber and light microscopy. The whole process of extraction and enumeration of oospores was repeated five times.

Oospore germination. $P$. capsici oospores extracted from the artificially infested soils were induced to germinate on the semiselective culture medium PARP (37) in petri plates. The spores were treated with $0.1 \% \mathrm{KMnO}_{4}$ for $10 \mathrm{~min}$ $(1,11)$, washed three times with sterile distilled water, and plated onto PARP medium. Two hundred oospores from each soil sample were plated (50 oospores per plate) for germination. The plates were incubated at $24^{\circ} \mathrm{C}$ in darkness for 9 days and the percentage of germinated spores was determined. Plugs of 5-mm diameter from the edge of the 10 growing colonies of germinated oospores were transferred onto lima bean agar (LBA; 23), grown at $24^{\circ} \mathrm{C}$ for 5 days, and the presence of $P$. capsici was determined on the basis of the sporangial morphology with light microscopy. Twelve representative cultures (three cultures per plate) were tested to verify identification of $P$. capsici with the PCR protocol described by Islam et al. (23).

DNA extraction. Oomycete and fungal isolates used in this study (Table 2) were maintained on LBA slants at room temperature. Mycelia for DNA extraction were prepared according to the method described by Islam et al. (23). DNA was extracted from oospores of $P$. capsici with the protocol reported by Gao et al. (16). The DNA concentrations were measured with a Genesys 10 spectrometer (Thermo Spectronic, Rochester, NY).

Primer and probe design. The sequences from the ITS1 and ITS2 regions and 5.8S ribosomal DNA gene of $P$. capsici (Fig. 1) were subjected to a database search using BLAST and FASTA programs, and these sequences were aligned using ClustalW package (42) to the same regions of 30 different species of Phytophthora to identify species-specific sequences. The regions of dissimilarity were used to design Taqman minor groove binding primers and probe with Primer Express 2.0 software (Applied Biosystems, Forest City, CA).

The ribosomal DNA sequences of $P$. capsici used for the sequence analysis were obtained from the GenBank database (Accession Nos. AF125008, AF129888, AF332266, AJ555612, AY742735, DQ464056, DQ464055, DQ464040, AB217670, EF053310, and EF053309). Also, the ribosomal DNA sequences from P. capsici isolates PC2, PC25, PP1, PP2, and 43-2 that were determined by Tian and Babadoost (43) were used for designing $P$. capsici primers (Pcap-q-1). Pcap-q-1 primers were: forward, 5'-GGA ACC GTA TCA ACC CTT TTA GTT G-3'; reverse, 5'CGC CCG GAC CGA AGT C-3'; and probe, 5'-6FAM-TCT TGT ACC CTA TCA TGG CG-MGBNFQ-3'.

In the relative QPCR assay, the primers (Pyth-q-2) and the probe used were designed by sequences of ribosomal DNA gene of Phytophthora and Pythium species (GenBank Accession Nos. AF125008, AF129888, AF332266, AJ555612, AY742735, AY590277, AY423301, AY590275, AF266779, AY26999,

Table 1. Soils used for the development of the method for extraction and enumeration of oospores of Phytophthora capsici in the soil

\begin{tabular}{|c|c|c|c|c|c|c|c|}
\hline Soil texture & Location $^{z}$ & Soil pH & $\begin{array}{c}\text { Organic matter } \\
(\%)\end{array}$ & $\begin{array}{c}\text { Sand } \\
(\%)\end{array}$ & $\begin{array}{l}\text { Silt } \\
(\%)\end{array}$ & $\begin{array}{l}\text { Clay } \\
(\%)\end{array}$ & $\begin{array}{c}\text { Oven-dried soil } \\
\text { wt of } 10 \mathrm{~g} \text { air-dried soil }\end{array}$ \\
\hline Sandy loam & Urbana & 5.5 & 2.0 & 77 & 16 & 7 & 9.1 \\
\hline Silt loam & Shawneetown & 5.9 & 2.5 & 18 & 69 & 13 & 8.1 \\
\hline Silt loam & Collinsville & 8.7 & 2.3 & 33 & 55 & 12 & 8.5 \\
\hline Silt loam & Pekin & 6.5 & 4.6 & 24 & 55 & 21 & 8.1 \\
\hline Silt clay & Champaign & 7.3 & 5.3 & 7 & 65 & 28 & 8.7 \\
\hline
\end{tabular}

z Towns in Illinois: Urbana and Champaign in Champaign County; Shawneetown in Gallatin County; Collinsville in Madison County; and Pekin in Tazewell County. 
AY986961, DQ059572, AB160845, and AF330171). Pyth-q-2 primers were: forward, 5'- GCA ACT TTC AGC AGT GGA TGT C-3'; reverse, 5'-TGC AAT TCG CAT TAC GTA TCG-3'; and probe, 5'VIC-CGA TGA AGA ACG CTG CGMGBNFQ-3'.

Primers were synthesized at the W. M. Keck Center for Functional and Comparative Genomics, University of Illinois at Urbana-Champaign. The probes were commercially synthesized by Applied Biosystems. The probes were labeled at the $5^{\prime}$ end with a fluorescent reporter dye: 6carboxyfluorescein (6-FAM) for the $P$. capsici probe (Pcap-q-1) and VIC (Applied Biosystems proprietary compound) for the Pythiaceae species probe (Phyt-q-2). The probes were labeled at the $3^{\prime}$ end with the minor groove binding nonfluorescent quencher (MGBNFQ).

Real-time QPCR amplification. The QPCR assays were conducted in a 96-well plate format with the ABI PRISM 7000 Sequence Detection System instrument and the software from PE Applied Biosystems (Foster City, CA). The manufacturer's instructions were followed except that 25- $\mu$ reaction mixtures (instead of 50 $\mu \mathrm{l})$ were used (17). Thermal cycling conditions consisted of $10 \mathrm{~min}$ at $95^{\circ} \mathrm{C}$ followed by 40 cycles of $15 \mathrm{~s}$ at $95^{\circ} \mathrm{C}$ and $1 \mathrm{~min}$ at $60^{\circ} \mathrm{C}$ in addition to a 2-min preincubation at $50^{\circ} \mathrm{C}$. QPCR was performed to test the specificity of the Taqman probes to the pathogen DNA. Five P. capsici isolates and

Table 2. Oomycete and fungal isolates used in the real-time quantitative polymerase chain reaction assays

\begin{tabular}{ll}
\hline Isolate & Species \\
\hline $15427^{\mathrm{v}}$ & Phytophthora capsici \\
PC-14 (A2) & P. capsici \\
PC-60 (A2) & P. capsici \\
PC-81 (A1) & P. capsici \\
PC-94 (A1) & P. capsici \\
$1025^{\mathrm{x}}$ & Hymenochaete fugilinosa \\
$1033^{\mathrm{x}}$ & Pythium ultimum \\
$1035^{\mathrm{x}}$ & Saprolegnia monilifera \\
$1042^{\mathrm{x}}$ & Klyveromyces piceae \\
AeILmy1 $1 \mathrm{a}^{\mathrm{y}}$ & Aphanomyces euteiches \\
Psj5-17y & P. sojae \\
Py2-1 & Pythium aphadernium \\
Pi24-1 & P. infestans \\
Illinois-1 & Aphanomyces euteiches \\
Illinois- $2^{\mathrm{z}}$ & P. sojae \\
\hline
\end{tabular}

${ }^{v}$ A1-mating type obtained from American Type Culture Collection Center (Manassas, VA).

${ }^{w}$ Isolates were collected from Illinois: PC-14 from watermelon in Pekin (Tazewell County); PC-60 from pumpkin and PC-94 from zucchini in Grant Park (Kankakee County); and PC-81 from pumpkin in Shawneetown (Gallatin County).

${ }^{x}$ Isolates were provided by J. Chee-Sanford,

United States Department of Agriculture, Agricultural Research Service, Urbana, IL.

${ }^{\mathrm{y}}$ Isolates were available in the oomycete and fungal isolates collection of M. Babadoost at the University of Illinois.

${ }^{\mathrm{z}}$ Isolates were provided by D. Malvick, University of Minnesota, St. Paul, MN. other oomycete and fungal species (Table 2) were used for this absolute QPCR assay. DNA extracts were diluted to $0.1 \mathrm{ng} / \mu \mathrm{l}$ prior to the QPCR tests. These tests were repeated twice.

The $\triangle \mathrm{Ct}$ PCR inhibition test, developed by Gao et al. (16), was used to test whether DNA extracts directly from oospores in the soil and oospores recovered from the soil by the sucrose-centrifugation method were PCR inhibitor-free. This test was based on QPCR assays of the $\beta$-actin gene from Meloidogyne javanica (Mj-ba) (36). The amplification of $M j-b a$ was measured in the QPCR assays without inhibitors and with soil extracts with possible inhibitors in the PCR mix. In this procedure, primers and probe for $M j-b a$ (36) were used instead of primers and probe for $P$. capsici. Amounts of $\beta$-actin DNA used were $7.5 \times$ $10^{-4} \mathrm{ng}$ (Test 1$)$ and $1.7 \times 10^{-5} \mathrm{ng}$ (Test 2).

QPCR assays for quantifying oospores. A QPCR assay was developed to determine the relationship between the number of $P$. capsici oospores and the quantity of $P$. capsici DNA extracted. Autoclaved soil samples were infested with $P$. capsici oospores as previously described. The oospores were extracted from the soil with the sieving-centrifugation method. A control soil sample, with no oospores incorporated, was included in the test. With the spore-counting chamber, the numbers of $P$. capsici oospores were adjusted to $10^{1}, 10^{1.5}, 10^{2}, 10^{2.5}, 10^{3}, 10^{3.5}$, $10^{4}, 10^{4.5}$, and $10^{5}$ spores per sample for DNA extraction. The control sample (extract of soil without oospores) and a negative control (molecular pure water) were included in each run. A subset of 10-fold dilution series of the total DNA extracted from $P$. capsici oospore samples, spanning from $1 \times 10^{-4}$ to $1 \times 10^{0} \mathrm{ng}$, was incorporated into each QPCR assay in triplicate to generate a standard curve. The tests were repeated five times.

\footnotetext{
A Phytophthora cryptogea (BWB12914) Phytophthora ramorum (BWB3202) Phytophthora sojae (BWB20265) Phytophthora megasperma (BWB12388) Phytophthora capsici( $\mathrm{PC}-25)$ Phytophthora infestans (BWB28612)

B Phytophthora cryptogea (BWB12914) Phytophthora ramorum (BWB3202) Phytophthora sojae (BWB20265) Phytophthora megasperma (BWB12388) Phytophthora capsici (PC-25) Phytophthora infestans (BWB28612)

C Phytophthora cryptogea (BWB12914) Phytophthora ramorum (BWB3202) Phytophthora sojae (BWB20265) Phytophthora megasperma (BWB12388) Phytophthora capsici( $\mathrm{PC}-25)$ Phytophthora infestans (BWB28612)
}

Quantifying $P$. capsici oospores in field soils. Eight commercial fields with a history of Phytophthora blight were sampled during the fall of 2004, after harvesting crops, for extraction and enumeration of $P$. capsici oospores. The fields had been planted to pumpkin, squash, or bell pepper either in 2004, 2003, or 2002. In each field, 20 soil subsamples were taken in a zigzag pattern from an area of 0.4 ha. A soil probe, with a diameter of $9.5 \mathrm{~mm}$, was used to take $0-$ to $20-\mathrm{cm}$ soil cores. The subsamples were mixed by adding all subsamples together, dividing the mixed soil into four parts, and remixing them again. This process was repeated four times to mix the soil subsamples thoroughly. The mixed samples were passed through a 2$\mathrm{mm}$ sieve. The soil samples were stored at $4^{\circ} \mathrm{C}$ until they were assayed for the presence of oospores. Five 10-g soil samples from each field were processed for extraction and quantification of oospores using the above-mentioned sieving-centrifugation method. The extracted oospores were used for QPCR testing. Additional soil samples from each field were processed to extract oospores for determining the rate of oospore germination.

DNA was extracted from oospores of $P$. capsici separated from field soils by the protocol reported by Gao et al. (16). DNA extracts from the oospores and a negative control (molecular water only), in triplicate, were tested to quantify $P$. capsici DNA.

Spores extracted from soil samples were treated with $0.1 \% \mathrm{KMnO}_{4}$ for $10 \mathrm{~min}$ $(1,11)$, washed three times with sterile distilled water, and plated onto PARP medium (37) in petri plates for spore germination. Two hundred oospores from each soil sample were plated (50 oospores per plate) onto the medium. The plates were incubated at $24^{\circ} \mathrm{C}$ in darkness for 9 days and the percentage of germinated spores

GGGGCTTCCGTCTGGCCGGCCGGTTTTCGGCTGGC GGGGCTTCTGTTCGGCTGGC-----TTCGGCTGGC TCGATGTCAAAGTCGGCGGC----TGGCTGCTG-T CTGGCCTGTAATGGGTCGGC----GTGCTGCTG-C TCCACGTGGAACCG--TATCAACCCTTTTAGTTGC CTTACTTGGCGGCGGCTGCTGGCTTTATTGCTGGC

TGGGTGGCG-------GCTCTATCATG-G-CGACC TGGGCGGCG-------GCTCTATCATG-G-CGAGC GTGGCGG--------GCTCTATCATG-GCGATTG TGGGCGG--------GCTCTATCATG-GGCGAGC GGGTCTTGT------ACCCTATCAT--GGCGAAT GGCTACTGCTGGGCGAGCCCTATCAAAAGGCGAGC

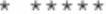

GCTTGGGCCTC--GGCCTGGGCTAGTAGCGTA--GCTTGAGCCTTCGGGTCTGAGCTAGTAGCCCAC-GTTTGGGTCCTC-CTCGTGGGGAACTGGATCATGA GTTTGGG-CTTC-GGCTCGAGCTAGTAGCTATCAA GTTTGGA-CTTC-GGTCCGGGCGAGTAGCTTTTTGTTTGGA-CTTC-GGTCTGAGCTAGTAGCTTTTTT $\star \star \star \star \star \star * \star * \star * \star *$

Fig. 1. Alignment of ITS region sequences of Phytophthora capsici and closely related Phytophthora species. The database accession reference codes are inside the parentheses. . capsici Taqman primer set: forward primer (A), oligonucleotide probe $(\mathbf{B})$, and reverse primer (reverse complement sequence) (C). Identical nucleotides are marked with an asterisk and gaps are indicated by dashes. 
was determined. Plugs of 5-mm diameter from the edge of the growing colonies of germinated oospores were transferred onto LBA (23), grown at $24^{\circ} \mathrm{C}$ for 5 days and the species were identified with light microscopy. The identification of the species was on the basis of sporangial morphology. Twenty-four representative cultures of $P$. capsici oospores recovered cultures per field) were grown in lima bean broth and tested for verification of $P$. capsici by the PCR protocol described by Islam et al. (23).

In this study, relative QPCR was used to determine DNA quantities of $P$. capsici oospores (target DNA) relative to the DNA of species of the Pythiaceae family (endogenous control). To use the $\Delta \Delta \mathrm{Ct}$ method, a validation test was carried out to determine if the amplification efficiency of the target DNA (Pcap-q-1) and the endogenous control DNA (Phyt-q-2) were equal. of $1 \times 10^{-2} \mathrm{ng}$ ribosomal DNA of $P$. capsici and $1 \times 10^{0} \mathrm{ng}$ ribosomal DNA of present species of the Pythiaceae family. The relative quantity of $P$. capsici DNA was determined by the formula $2^{-\Delta \Delta \mathrm{Ct}}$, as described by Livak and Schmittgen (29).

Data analysis. The data collected from the different experiments were analyzed by SAS procedures (SAS Institute, Cary, NC). Normality was tested with PROC UNIVARIATE. Analysis of variance (ANOVA) procedures were conducted and equality of variances was tested with Levene's test in the MEANS statement. All of the analyses of the oospore extraction data and DNA quantities were conducted and quadratic coefficients of the regresfrom eight commercial fields (three The calibrator was used at a concentration using $\log _{10}$-transformed data. The linear

sions were determined with single-degreeof-freedom polynomial orthogonal contrasts in the MIXED procedure of SAS with the type III method. There were no significant differences among different oospore extractions $(P>0.3)$. Thus, all the oospore extraction data were combined for analyses.

\section{RESULTS}

Extraction and enumeration of oospores in soil. The isolates of $P$. capsici used for oospore production yielded from $4.41 \times 10^{5}$ to $6.72 \times 10^{5}$ (mean $\left.5.56 \times 10^{5}\right)$ oospores per plate after 2 months. P. capsici oospores were recovered from all five artificially infested soil samples. No oospores were recovered from soil samples without oospore incorporation. The recovery rates of $P$. capsici oospores were 21.4, $43.7,53.6,60.3$, and $79.8 \%$ from soil samples containing $10^{1}, 10^{2}, 10^{3}, 10^{4}$, and $10^{5}$ oospores per $10 \mathrm{~g}$, respectively. There was no significant difference in oospore recovery among the soil samples with different textures. The relationship between the number of oospores recovered from the soil and the number of oospores incorporated into the soil was $\hat{Y}=-0.95+1.31 X-$ $0.03 X^{2}\left(R^{2}=0.98, P<0.001\right)$, in which $\hat{Y}$ $=\log _{10}$ of number of oospores recovered from the soil, and $X=\log _{10}$ of number of oospores incorporated into the soil (Fig. 2). The standard error for the intercept and the linear and quadratic coefficients in the model were $0.11,0.08$, and 0.01 , respectively.

The percentage of oospores recovered from soil samples with $10^{1}$ oospores per 10 $\mathrm{g}$ was significantly lower than the percentage of oospores recovered from all other oospore densities (Table 3). Also, the per-

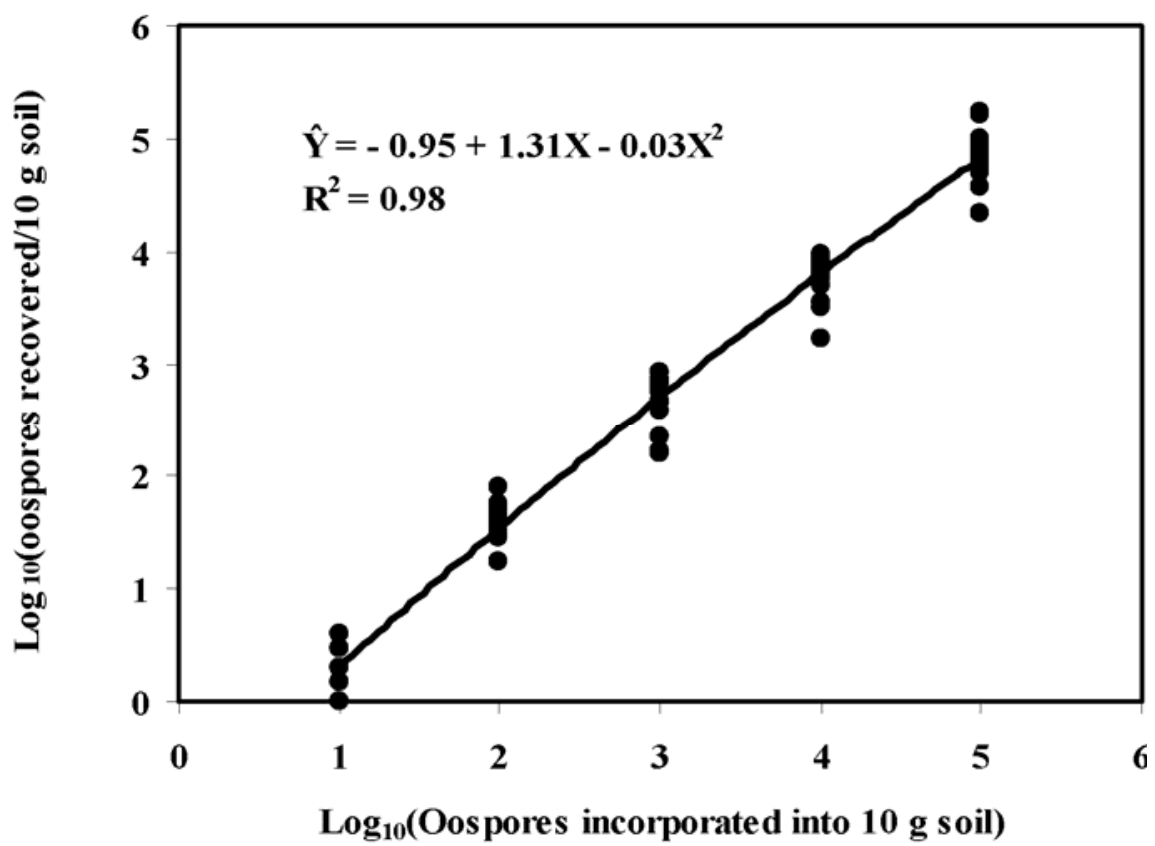

Fig. 2. Relationship between Phytophthora capsici oospores recovered from the soil and oospores incorporated into the soil. centage of oospores recovered from soil samples with $10^{2}$ oospores per $10 \mathrm{~g}$ was significantly lower than with $10^{4}$ and $10^{5}$, but not different from that with $10^{3}$. Similarly, the percentage of oospores recovered from soil samples with $10^{3}$ oospores per $10 \mathrm{~g}$ was significantly lower than the percentage of oospores recovered from samples with $10^{5}$, but not different from that with $10^{4}$. There was significant difference in oospore recovery between soil samples containing $10^{4}$ and $10^{5}$ oospores per $10 \mathrm{~g}$.

Specificity and sensitivity of QPCR assays. All five isolates of $P$. capsici tested (Table 2) were amplified by utilizing the QPCR protocol with Pcap-q-1 primers. There was no DNA amplification from the extracts from soil samples without $P$. capsici, sterile water, isolates of $P$. sojae, $P$. infestans, and Pythium species, or fungal species tested. DNA of $P$. capsici oospores as low as $1 \times 10^{-4} \mathrm{ng}\left(\mathrm{s}=1.3 \times 10^{-5}, \mathrm{CV}=\right.$ $13.3 \%$ ) was detected by the amplification (Fig. 3).

Effects of DNA extracts on $\beta$-actin amplification. Amplification of DNA directly extracted from soil was completely inhibited. The DNA extracted from oospores recovered from soil with the sieving-centrifugation procedure showed no PCR inhibition. The Ct with $7.5 \times 10^{-4} \mathrm{ng}$ (Test 1 ) and $1.7 \times 10^{-5} \mathrm{ng}$ (Test 2 ) of $\beta$ actin DNA was 23.5 and 28.3, respectively. The average $\mathrm{Ct}$ for the samples with $\beta$ actin DNA and P. capsici DNA were 23.7 (Test 1) and 28.5 (Test 2). The observed $\beta$ actin $\Delta \mathrm{Ct}$ ranged from 0.0 to 0.9 . The coefficient of variation of the $\mathrm{Ct}$ for both tests was less than $1 \%$ (Fig. 3).

PCR quantification of $P$. capsici oospores. The DNA quantities corresponding to $10^{1}, 10^{1.5}, 10^{2}, 10^{2.5}, 10^{3}, 10^{3.5}, 10^{4}$, $10^{4.5}$, and $10^{5}$ oospores were $1.4 \times 10^{-4}, 1.9$ $\times 10^{-4}, 3.5 \times 10^{-4}, 9.0 \times 10^{-4}, 3.2 \times 10^{-3}, 1.6$ $\times 10^{-2}, 1.5 \times 10^{-1}, 1.2 \times 10^{0}$, and $1.7 \times 10^{1}$

Table 3. Recovery of Phytophthora capsici oospores incorporated into soil samples with the sieving-centrifugation method and quantities of recovered oospores

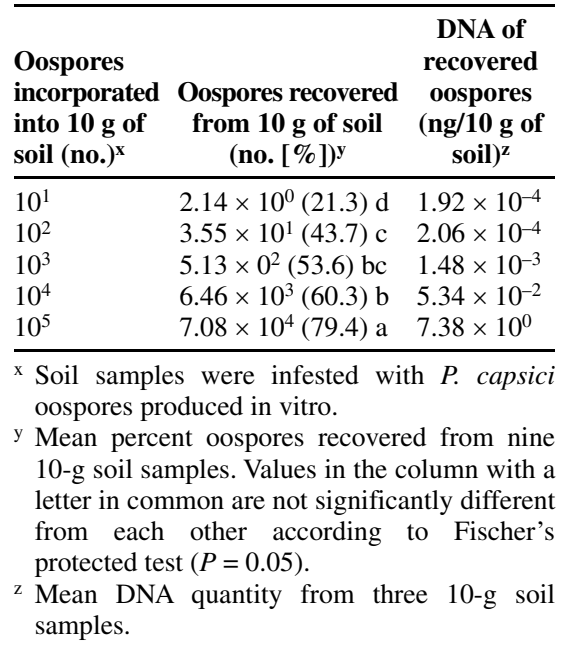


ng, respectively. The relationship between the number of oospores and DNA quantities of $P$. capsici was $\hat{Y}=-3.57-0.54 X+$ $0.30 X^{2}\left(R^{2}=0.93, P<0.001\right)$, in which $\hat{Y}=$ $\log _{10}$ (nanogram of $P$. capsici DNA) and $X=$ $\log _{10}$ (number of oospores) (Fig. 4). The standard error for the intercept and linear and quadratic coefficients of the model were $0.18,0.14$, and 0.02 , respectively.

The relationship between the DNA quantities of $P$. capsici oospores recovered from soil samples with $10^{2}, 10^{3}, 10^{4}$, and $10^{5}$ spore densities in the soil (Table 3) was determined by $\hat{Y}=-3.53-0.73 X+$ $0.32 X^{2}\left(R^{2}=0.955, P<0.05\right)$, in which $\hat{Y}$ $=\log _{10}$ (DNA quantity of $P$. capsici oospores recovered from the soil) and $X=$ $\log _{10}$ (number of $P$. capsici oospores incorporated into the soil).

Quantifying $P$. capsici oospores in field soils. The number of oospores recovered from commercial fields in Illinois ranged from 680 to 2,800 per $10 \mathrm{~g}$ of soil (Table 4). The average diameter of oospores extracted from the soils was $27.8 \mu \mathrm{m}$. There was no significant difference in diameter of oospores recovered from the different fields. Percentage of germinated oospores recovered from soils ranged from 40.9 to $64.3 \%$. There were significant differences in percent oospores germinated among the fields. Percent germinated oospores identified as $P$. capsici ranged from 9.2 to $18.5 \%$ (mean $14.7 \%$ ) (Table 4).

DNA of $P$. capsici oospores was amplified in soil extracts from all fields tested. P. capsici DNA in the field soils ranged from $6.6 \times 10^{-4} \mathrm{ng}$ (217 oospores) to 7.7 $\times 10^{-3} \mathrm{ng}(1,873$ oospores $)$ per $10 \mathrm{~g}$ of air-dried soil (Table 5). There were significant differences in the density of $P$. capsici oospores among the fields. The coefficient of variation of $\mathrm{Ct}$ for $P$. capsici DNA (target DNA) was 3\% and for the endogenous control, it was $13 \%$. The mean relative quantity (RQ) $\left(2^{-\Delta \Delta C t}\right)$ values for the eight field soils ranged from 0.22 to 3.58 .

With light microscopy, conidia of Alternaria spp. were observed in the spore suspensions extracted from soils. After culturing the extracted spores from soil samples from commercial fields, $P$. sojae and $P$ thium spp. were identified in the colonies formed from germinated spores.

\section{DISCUSSION}

The sieving density separation in the sucrose solution method has been used to extract mycorrhizal and smut fungi from the soil $(5,9,10,22$,$) . Also, the sucrose$ solution method has long been used to separate nematodes from the soil (24). This study, however, is the first report of using a sieving-centrifugation method utilizing sucrose solution for extraction of oospores of $P$. capsici from the soil.

The sieving-centrifugation procedure described in this report was developed after numerous tests with different soil textures, soil amounts, sucrose concentrations, centrifugation speeds, centrifugation times, and oospore densities. The described protocol was the most efficient for maximum extraction of $P$. capsici oospores from soils. Utilizing the sieving-centrifugation method, we were able to recover $P$. density as low as one spore per gram of soil, although the overall extraction efficiency of oospores was not $100 \%$. There rates of $P$. capsici oospores from all five soils with different textures used in this capsici oospores from soil with a spore were no significant differences in recovery

study. Also, with the sieving-centrifugation method, $P$. capsici oospores were recovered from soils collected from commercial fields in different locations in Illinois. Thus, the described sieving-centrifugation procedure is a reliable method to separate $P$. capsici oospores from soil to quantify the oospore density.

Furlan et al. (15) reported that sucrose was not a good separation medium for spores of endomycorrhizal fungi because spores become dehydrated and collapse and this may affect identification of the fungus and viability of spores. But, Ianson and Allen (22) used a $2 \mathrm{M}$ sucrose solution

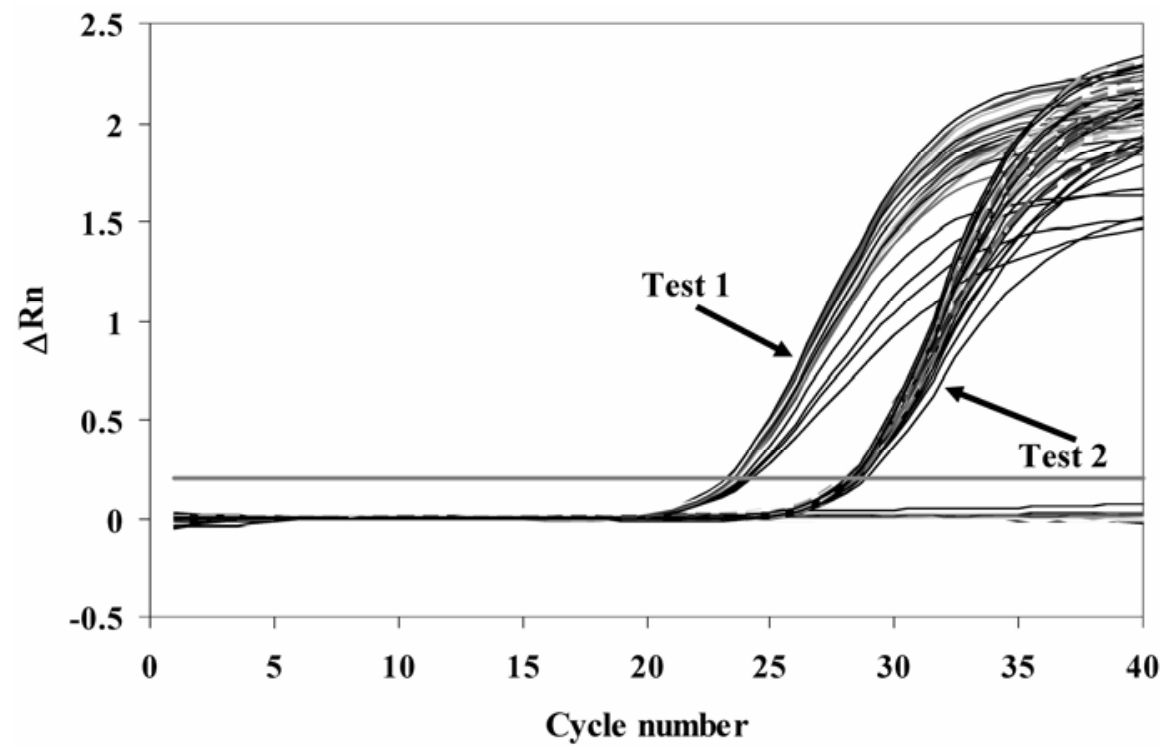

Fig. 3. Effect of DNA extracts from oospores separated from the soil on $\beta$-actin amplification by realtime quantitative polymerase chain reaction. There was either $7.5 \times 10^{-4}$ or $1.7 \times 10^{-5} \mathrm{ng}$ of $\beta$-actin in each reaction well (25- $\mu$ l reaction mixture). Amplification plot shows cycle number versus normalized fluorescence $(\Delta \mathrm{Rn})$. The fluorescent intensity signal threshold was 0.2 (solid horizontal line).

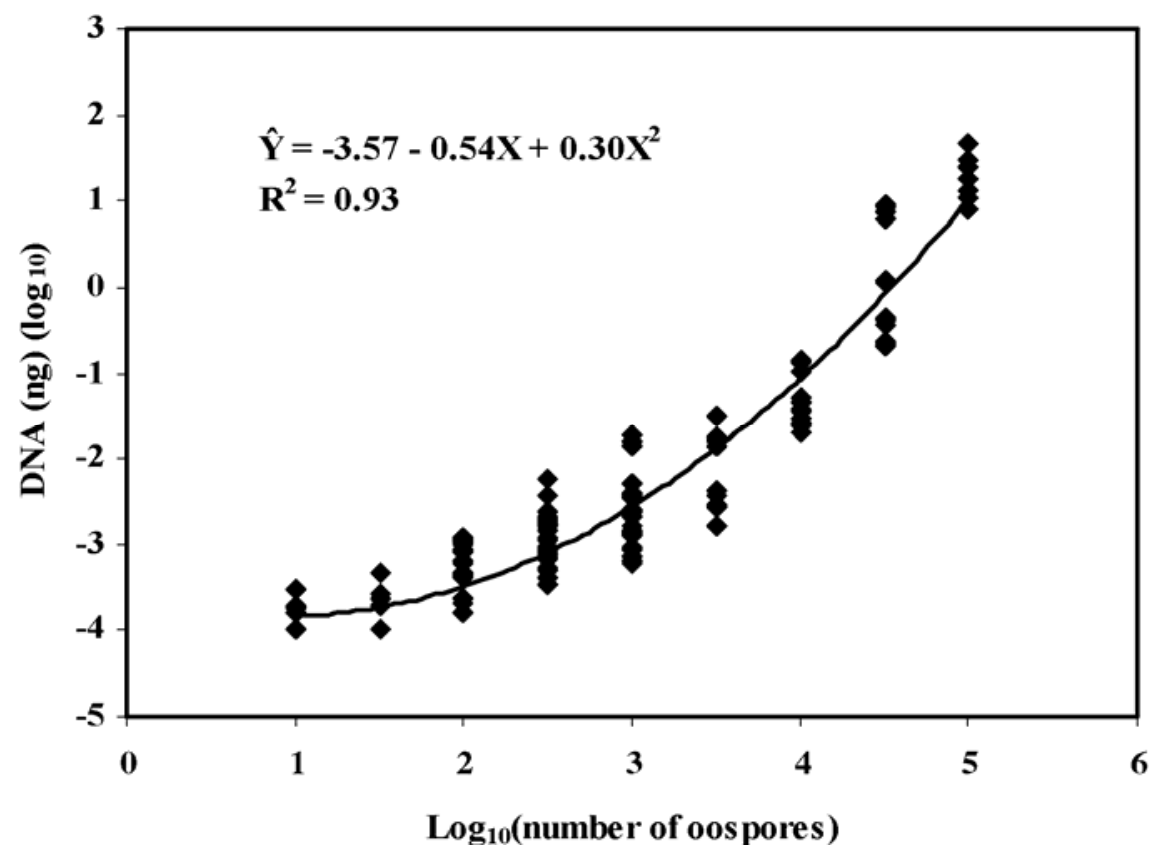

Fig. 4. Relationship between number of oospores and absolute DNA quantity (nanogram) of Phytophthora capsici in quantitative polymerase chain reaction assays. 
to extract spores of vesicular-arbuscular mycorrhizal fungi from soil and found that exposing the spores to sucrose for $24 \mathrm{~h}$ did not cause significant damage. Also, Babadoost and Mathre (5) used 1.6 M sucrose solution for extracting teliospores of Tilletia spp. from soil and reported no adverse effect of sucrose solution on teliospore morphology and germination. In this study, with the same concentration of sucrose, we found neither collapse of cell wall nor reduction in germination of oospores.

The sieving-centrifugation method alone cannot be used to determine the number of $P$. capsici oospores in the soil because spores of other oomycetes and fungi are extracted along with $P$. capsici oospores. For example, in this study, oospores of
Phytophthora and Pythium spp. and conidia of Alternaria spp. were extracted along with $P$. capsici oospores from field soils. Also, along with $P$. capsici oospores, spores of endomycorrhizal fungi (22) and smut fungi (5) could be extracted from the soil with the sieving-centrifugation method. With light microscopy, oospores of oomycetes can be easily identified from fungal spores, but identification of oospores of $P$. capsici from oospores of other oomycetes on the basis of oospores morphology is not possible. Utilizing the QPCR procedure developed in this study, we assessed the number of $P$. capsici oospores extracted from the soil. The QPCR method, however, cannot determine viability of the oospores. The germination test of the extracted oospores is required to deter-

Table 4. Total number and percentage of germinated oospores of species of the Pythiaceae family in commercial fields in Illinois in 2005

\begin{tabular}{|c|c|c|c|c|}
\hline Location $^{w}$ & $\begin{array}{l}\text { Total number } \\
\text { of oospores/ } \\
10 \mathrm{~g} \text { of soil }\end{array}$ & $\begin{array}{l}\text { Oospore } \\
\text { diameter } \\
(\mu \mathrm{m})^{\mathrm{y}}\end{array}$ & $\begin{array}{c}\begin{array}{c}\text { Oospore } \\
\text { germination }\end{array} \\
(\%)^{\mathrm{z}}\end{array}$ & $\begin{array}{c}\text { Geminated } \\
\text { oospores } \\
\text { identified } \\
\text { as } P \text {. capsici } \\
(\%)\end{array}$ \\
\hline Forest city & $1,783 a b c$ & $28.1 \pm 4.4$ & $61.3 \mathrm{abc}$ & 13.6 \\
\hline Green Valley & $1,183 \mathrm{abc}$ & $27.5 \pm 3.8$ & $64.3 \mathrm{a}$ & 12.3 \\
\hline Green Valley & $1,183 \mathrm{abc}$ & $27.1 \pm 4.0$ & $62.3 \mathrm{ab}$ & 18.4 \\
\hline Green Valley & $2,800 \mathrm{a}$ & $26.9 \pm 3.7$ & $47.6 \mathrm{~cd}$ & 10.8 \\
\hline Pekin & $2,183 \mathrm{ab}$ & $28.5 \pm 2.3$ & $49.7 \mathrm{bcd}$ & 18.5 \\
\hline Shawneetown & $1,533 \mathrm{abc}$ & $28.6 \pm 2.7$ & $57.3 \mathrm{abc}$ & 17.4 \\
\hline Shawneetown & $1,800 \mathrm{abc}$ & $27.4 \pm 3.1$ & $62.0 \mathrm{ab}$ & 17.1 \\
\hline Shawneetown & $680 \mathrm{c}$ & $28.1 \pm 2.8$ & $40.9 \mathrm{~d}$ & 9.2 \\
\hline
\end{tabular}

w Towns in Illinois: Forest City in Mason County; Green Valley and Pekin in Tazewell County; and Shawneetown in Gallatin County.

${ }^{x}$ Mean number of oospores extracted from five $10 \mathrm{~g}$ air-dried soil samples. Values in the column with a letter in common are not significantly different from each other according to Fischer's protected test $(P=0.05)$.

${ }^{\mathrm{y}}$ Mean diameter of 15 arbitrarily selected oospores.

${ }^{\mathrm{z}}$ Mean of four 50-oospore replications. Values in the column with a letter in common are not significantly different from each other according to Fischer's protected test $(P=0.05)$.

Table 5. Quantitative polymerase chain reaction assays of total DNA of Phytophthora capsici oospores extracted from commercial fields in Illinois

\begin{tabular}{|c|c|c|c|c|c|}
\hline \multirow[b]{3}{*}{ Location" } & \multicolumn{3}{|c|}{ Relative quantity } & \multicolumn{2}{|c|}{ Absolute quantity } \\
\hline & \multicolumn{2}{|c|}{$\mathbf{C t}^{\mathrm{v}}$} & \multirow[b]{2}{*}{$\mathbf{R Q}^{\mathbf{x}}$} & \multirow{2}{*}{$\begin{array}{c}P \text {. capsici } \\
\text { DNA } \\
\text { (ng/10 g of soil)y }\end{array}$} & \multirow{2}{*}{$\begin{array}{c}\text { P. capsici } \\
\text { oospores } \\
(\text { no./10 g of soil })^{2}\end{array}$} \\
\hline & Pcap-q-1 & Pyth-q-2 & & & \\
\hline Forest City & 34.1 & 30.1 & $3.59 \pm 0.9$ & $4.0 \times 10^{-3}$ & $1,116 \mathrm{ab}$ \\
\hline Green Valley & 34.9 & 26.8 & $0.22 \pm 0.7$ & $2.5 \times 10^{-3}$ & $767 \mathrm{abc}$ \\
\hline Green Valley & 35.2 & 30.8 & $2.94 \pm 0.7$ & $9.8 \times 10^{-4}$ & $342 \mathrm{bc}$ \\
\hline Green Valley & 33.1 & 28.5 & $2.48 \pm 0.8$ & $7.7 \times 10^{-3}$ & $1,873 \mathrm{a}$ \\
\hline Pekin & 35.0 & 28.7 & $0.77 \pm 0.5$ & $2.3 \times 10^{-3}$ & $741 \mathrm{abc}$ \\
\hline Shawneetown & 35.8 & 30.9 & $2.02 \pm 0.9$ & $1.5 \times 10^{-3}$ & $467 \mathrm{bc}$ \\
\hline Shawneetown & 35.2 & 30.6 & $2.51 \pm 0.4$ & $2.1 \times 10^{-3}$ & $650 a b c$ \\
\hline Shawneetown & 37.1 & 30.1 & $0.47 \pm 0.9$ & $6.6 \times 10^{-4}$ & $217 \mathrm{c}$ \\
\hline
\end{tabular}

$\mathrm{v}$ Threshold cycle $(\mathrm{Ct})$ number when fluorescence intensity of the sample exceeded background fluorescence intensity. The fluorescent intensity signal threshold was 0.2 . The $\mathrm{Ct}$ value is the mean of three sample replicates. Pcap-q-1 and Phyt-q-2 primers were designed for amplification of ribosomal DNA of P. capsici and ribosomal DNA of species of the Pythiaceae family, respectively.

${ }^{\text {w }}$ Towns in Illinois where the sampled commercial fields infested with $P$. capsici are located. Forest City, Green Valley and Pekin, and Shawneetown are in Mason, Tazewell, and Gallatin counties, respectively.

${ }^{\mathrm{x}} \mathrm{RQ}=\left(2^{-\Delta \Delta \mathrm{Ct}}\right)$ and is the relative quantity of DNA of $P$. capsici.

${ }^{\mathrm{y}}$ Mean of $P$. capsici DNA from three 10-g soil samples.

${ }^{\mathrm{z}}$ Number of oospores was determined by the equation $\hat{Y}=-3.57-0.54(X)+0.30\left(X^{2}\right)$, in which $\hat{Y}=$ $\log _{10}$ (DNA nanogram) and $X=\log _{10}$ (oospore number). Values in the column with a letter in common are not significantly different from each other according to Fischer's protected test $(P=$ $0.05)$. mine whether or not the oospores in the soil are viable.

Because of the presence of PCR inhibitors in the soil, direct assay of $P$. capsici oospores in the soil with the QPCR procedure was unsuccessful. However, by utilizing sieving-centrifugation procedures, the PCR inhibitors in the soil were eliminated. Several studies have been conducted to eliminate PCR inhibitors from nucleic acid extracts $(16,31,44,45)$. The sieving-centrifugation procedure described in this report is an easy solution for eliminating PCR inhibitors in the soil extracts used in the QPCR method.

Only oospores were present in the soil extracts on the basis of examination of the extracts from artificially and naturally infested soils with light microscopy. No hyphal fragments, encysted zoospores, sporangia, or chlamydospores were observed in the extracts. Thus, extracted $P$. capsici DNA was considered to be oospore DNA only. Consequently, the number of $P$. capsici oospores in the soil could be determined by $\hat{Y}=-3.53-0.73 X+0.32 X^{2}\left(R^{2}=\right.$ $0.95, P<0.05$ ), in which $\hat{Y}=\log _{10}$ (DNA quantity of $P$. capsici oospores recovered from the soil) and $X=\log _{10}$ (number of $P$. capsici oospores incorporated into the soil). The number of oospores in the soil can be calculated according to the formula $X=\left[-b+\right.$ square root of $\left.\left(b^{2}-4 a c\right)\right] /(2 a)$ in the quadratic equation $\left(a X^{2}+b X+c=0\right)$.

The QPCR method used in this study is based on the amplification of ITS region of the ribosomal DNA of $P$. capsici. The ITS region has been reported to be a reliable region for specific amplification of $P$. capsici $(23,28,39,41)$. Silvar et al. (41) quantified ribosomal DNA of $P$. capsici in pepper plants with absolute QPCR with SYBR green primers with an amplicon of 452 bases. In our study, ribosomal DNA of $P$. capsici was quantified with a set of primers and a TaqMan probe with an amplicon of 74 bases. In both studies, segments of the same regions of the $5.8 \mathrm{~S}$ ribosomal DNA gene of $P$. capsici were amplified. Our procedure did not amplify DNA of $P$. sojae, P. infestans, Pythium spp., Aphanomyces euteiches, Saprolegnia monilifera, or fungal species tested. Thus, this procedure is highly specific and sensitive for detecting $P$. capsici since it detected as low as $1 \times 10^{-4} \mathrm{ng}$ of DNA.

Germination of oospores is essential for determining density of viable oospores of P. capsici in the soil. However, it should be mentioned that the rate of germinated oospores, utilizing current cultural methods $(1,11)$, may underestimate the number of viable oospores of $P$. capsici in the soil because: (i) percentage of germination of $P$. capsici oospores on culture media is usually less than 50\%; and (ii) colonies of $P$. capsici originating from oospores may be outgrown by closely related oomycete spp., particularly Pythium spp. Thus, further investigations may improve germina- 
tion of $P$. capsici oospores in culture plates and enhance accuracy of assessment of viable oospores of $P$. capsici in the soil.

The protocol of combining sucrose-centrifugation and QPCR methods developed in this study can be used to determine distribution of $P$. capsici oospores in fields and investigate biology and ecology of $P$. capsici. The findings of this study can also be employed to develop effective cropping systems for management of Phytophthora blight caused by $P$. capsici. In addition, the procedures reported in this paper could be adapted for assessing the presence of other soilborne plant pathogens, particularly oomycetes, in the soil.

\section{ACKNOWLEDGMENTS}

This research was supported in part by funds from USDA-CREES-NCR-SARE (agreement 2003-38640-13225) and Nestle Food Company. We would like to thank J. Chee-Sanford, L. Connor, D. Malvick, and E. Grunden for supplying fungal oomycete isolates; X. Gao for providing protocol for testing and eliminating PCR inhibitors; N. Atibalentja for assisting with DNA absorbance measurements; and N. McCoppin for her assistance in using the DNA centrifugal concentrator.

\section{LITERATURE CITED}

1. Ann, P. J., and Ko, W. H. 1988. Induction of oospore germination of Phytophthora parasitica. Phytopathology 78:335-338.

2. Avrova, A. O., Venter, E., Birch, P. R., and Whisson, S. C. 2003. Profiling and quantifying differential gene transcription in Phytophthora infestans prior to and during the early stages of potato infection. Fungal Genet. Biol. 40:4-14.

3. Babadoost, M. 2000. Outbreak of Phytophthora foliar blight and fruit rot in processing pumpkin fields in Illinois. Plant Dis. 84:1345.

4. Babadoost, M., and Islam, S. Z. 2003. Fungicide seed treatment effects on seedling damping-off of pumpkin caused by Phytophthora capsici. Plant. Dis. 87:63-68.

5. Babadoost, M., and Mathre, D. E. 1998. A method for extraction and enumeration of teliospores of Tilletia indica, T. controversa, and T. barclayana in soil. Plant Dis. 82:13571361.

6. Bach, H. J., Jessen, I., Schloter, M., and Munch, J. C. 2003. A TaqMan-PCR protocol for quantification and identification of the phytopathogenic Clavibacter michiganensis subspecies. J. Microbiol. Methods 52:85-91.

7. Bower, J. H., and Mitchell, D. J. 1991. Relationship between inoculum level of Phytophthora capsici and mortality of pepper. Phytopathology 81:178-184.

8. Cao, A. X., Liu, X. Z., Zhu, S. F., and Lu, B. S. 2005. Detection of the pinewood nematode, Bursaphelenchus xylophilus, using a real-time polymerase chain reaction assay. Phytopathology $95: 566-571$

9. Daniels, B. A., and Skipper, H. D. 1982. Methods for recovery and quantitative estimation of propagules from soil. Pages 29-35 in: Methods and Principles of Mycological Research. N. C. Schenck, ed. American Phytopathological Society, St. Paul, MN.

10. Datnoff, L. E., Royer, M. H., Bonde, M. R., and Prescott, J. M. 1988. A quantitative method for estimation of teliospores of Tilletia indica in soil. Plant Dis. 72:209-212.

11. El-Hamalawi, Z. A., and Erwin, D. C. 1986. Physical, enzymatic, and chemical factors affecting viability and germination of oospores of Phytophthora megasperma f. sp. medicaginis. Phytopathology 76:503-507.

12. Erwin, D. C., and Ribeiro, O. K. 1996. Phytophthora Diseases Worldwide. American Phytopathological Society, St. Paul, MN.

13. Eun, A. J. C., Seol, M. L., and Wong, S. M. 2000. Simultaneous quantitation of two orchard viruses by the Taqman real-time RTPCR. J. Virol. Methods 87:151-160.

14. Filion, M., St-Arnaud, M., and Jabali-Hare, S. H. 2003. Direct quantification of fungal DNA from soil substrate using real-time PCR. J. Microbiol. Methods 53:67-76.

15. Furlan, V., Bratsch, H., and Fortin, J. A. 1980. Media for density gradient extraction of endomycorrhizal spores. Trans. Br. Mycol. Soc. 57:335-338.

16. Gao, X., Jackson, T. A., Lambert, K. N., Li, S., Hartman, G. L., and Niblack, T. L. 2004. Detection and quantification of Fusarium solani f. sp. glycines in soybean roots with real-time quantitative polymerase chain reaction. Plant Dis. 88:1372-1380.

17. Gibson, U. E., Heid, C. A., and Williams, P. M. 1996. A novel method for real-time quantitative RT-PCR. Genome Res. 6:995-1001.

18. Hausbeck, M. K., and Lamour, K. H. 2004. Phytophthora capsici on vegetable crops: Research progress and management challenges. Plant Dis. 88:1292-1303.

19. Hayden, K. J., Rizzo, D., Tse, J., and Garbelotto, M. 2004. Detection and quantification of Phytophthora ramorum from California forest using a real-time polymerase chain reaction assay. Phytopathology 94:1075-1083.

20. Higuchi, R., Fockler, C., Dollinger, G., and Waterson, R. 1993. Kinetic PCR analysis: Real-time monitoring of DNA amplification reactions. Biotechnology 11:1026-1030.

21. Hwang, B. K., Kim, Y. J., and Kim, C. H. 1996. Differential interactions of Phytophthora capsici isolates with pepper genotypes at various growth stages. Eur. J. Plant Pathol. 102:311-316

22. Iason, D. C., and Allen, M. F. 1986. The effects of soil texture on extraction of vesiculararbuscular mycorrhizal fungal spores from arid sites. Mycology 78:164-168.

23. Islam, Z., Babadoost, M., Lambert, K. N., Ndeme, A., and Fouly, H. M. 2005. Characterization of Phytophthora capsici isolates from processing pumpkin in Illinois. Plant. Dis. 89:191-197.

24. Jenkins, W. R. 1964. A rapid centrifugal-flotation technique for separating nematodes from soil. Plant Dis. Rep. 48:692.

25. Jones, K., and Shew, H. D. 1988. Immunoassay procedure for the detection of Phytophthora parasitica var. nicotianae in soil (Abstr.). Phytopathology 78:1577.

26. Larkin, R. P., Ristaino, J. B., and Campbell, C. L. 1995. Detection and quantification of Phytophthora capsici in soil. Phytopathology 85:1057-1063.

27. Lee, B. K., Kim, B. S., Chang, S. W., and Hwang, B. K. 2001. Aggressiveness to pumpkin cultivars of isolates of Phytophthora capsici from pumpkin and pepper. Plant Dis. 85:497-500.

28. Lee, S. B., and Taylor, J. W. 1992. Phylogeny of five fungus-like protoctistan Phytophthora species, inferred from the internal transcribed spacers of ribosomal DNA. Mol. Biol. Evol.
9:636-653.

29. Livak, K. J., and Schmittgen, T. D. 2001. Analysis of relative gene expression data using real-time quantitative $\mathrm{PCR}$ and the $2^{-\Delta \Delta C t}$ method. Methods 25:402-408.

30. Malajczuk, N., Bowen, G. D., and Greenhalgh, F. C. 1978. A combined fluorescent antibody and soil sieving technique to count chlamydospores of Phytophthora cinnamomi in soil. Soil Biol. Biochem. 10:437-438.

31. Malvick, D. K., and Grunden, E. 2005. Isolation of fungal DNA from plant tissues and removal of DNA amplification inhibitors. Mol. Ecol. 5:958-960.

32. Martin, R. R., James, D., and Lévesque, C. A 2000. Impacts of molecular diagnostic technologies on plant disease management. Annu. Rev. Phytopathol. 38:207-239.

33. Masago, H., Yoshikawa, M., Fukuda, M., and Nakanishi, K. 1977. Selective inhibition of $P y$ thium spp. on a medium for direct isolation of Phytophthora spp. from soils and plants. Phytopathology 67:425-428.

34. Mavrodieva, V., Levy, L., and Gabriel, D. W. 2004. Improved sampling methods for realtime polymerase chain reaction diagnosis of citrus canker from field samples. Phytopathology 94:61-68.

35. Miller, S. A., Madden, L. V., and Schmitthenner, A. F. 1997. Distribution of Phytophthora spp. in field soils determined by immunoassay. Phytopathology 87:101-107.

36. Painter, J. E., and Lambert, K. N. 2003. Meloidogyne javanica chorismate mutase transcript expression profile using real-time quantitative RT-PCR. J. Nematol. 35:82-87.

37. Papavizas, G. S., Bowers, J. H., and Johnson, S. A. 1981. Selective isolation of Phytophthora capsici from soils. Phytopathology 71:129133.

38. Ristaino, J. B. 1990. Intraspecific variation among isolates of Phytophthora capsici from pepper and cucurbit fields in North Carolina. Phytopathology 80:1253-1259.

39. Ristaino, J. B., Madritch, M., Trout, C. L., and Parra, G. 1998. PCR amplification of ribosomal DNA for species identification in the plant pathogen genus Phytophthora. Appl. Environ. Microbiol. 64:948-953.

40. Silvar, C., Diaz, J., and Merino, F. 2005. Realtime polymerase chain reaction quantification of Phytophthora capsici in different pepper genotypes. Phytopathology 95:1423-1429.

41. Silvar, C., Duncan, J. M., Cooke, D. E. L., Williams, N. A., Diaz, J., and Merino, F 2005. Development of specific PCR primers for identification and detection of Phytophthora capsici Leon. Eur. J. Plant Pathol. 112:43-52.

42. Thompson, J. D., Higgins, D. G., and Gibson, T. J. 1994. CLUSTAL W: Improving the sensitivity of progressive multiple sequence alignment through sequence weighting, positionspecific gap penalties and weight matrix choice. Nucleic Acids Res. 22:4673-4680.

43. Tian, D., and Babadoost, M. 2004. Host range of Phytophthora capsici from pumpkin and pathogenicity of isolates. Plant Dis. 88:485489.

44. Van de Graaf, P., Lees, A. K., Cullen, D. W and Duncan, J. M. 2003. Detection and quantification of Spongospora subterranea in soil, water and plant tissue samples using real-time PCR. Eur. J. Plant Pathol. 109:589-597.

45. Wilson, I. G. 1997. Inhibition and facilitation of nucleic acid amplification. Appl. Environ. Microbiol. 63:2853-2858. 